\title{
Intenzív családmegtartó szolgáltatás - a koragyermekkori intervenció egy lehetséges változata
}

\author{
Bányai Emőke
}

Károli Gáspár Református Egyetem, Tanítóképző Főiskolai Kar

\begin{abstract}
Absztrakt: Az intenzív családmegtartó szolgáltatások konkrét, gyakorlati és terápiás hatású szociálismunka-beavatkozások együttesét jelentik, melyet általában egy magasan képzett szociális munkás nyújt rendszerint időhatáros formában, általában 3-6 hónapig. Céljuk a szülők megerösitése annak érdekében, hogy gyerekeiket sikeresen tudják nevelni. A szolgáltatásokat az egyedi család szükségleteihez igazodva olyan krízishelyzetbe került családoknak nyúitják, ahonnan a gyermek(ek)et egyébként ki kellene emelni súlyos veszélyeztetettségük miatt. Az intenzív családmegtartó szolgáltatások nemcsak kisgyermekes családokra irányulnak, de amennyiben 0-5 éves korú gyerek van a családban, a koragyerekkori intervenció egyik lehetséges formáját jelentik.
\end{abstract}

Kulcsszavak: szociális munka, intenzív családmegtartó szolgáltatás, gyermekjólét, gyermekvédelem, koragyermekkori intervenció

\section{Előzmények}

Az 1980-as évektöl kezdve a legtöbb fejlett ország gyermekvédelmi gyakorlatában alapvető paradigmaváltás zajlott le ${ }^{1}$. Korábban a beavatkozások legfontosabb célja az volt, hogy a gyermeket megvédjék a veszélyeztető környezet káros hatásaitól, akár azon az áron is, hogy az eredeti miliőből kiemelték, intézménybe, vagy más, jobban működő családba helyezték; elszakítva ezzel attól a családtól, ahova született. A társadalom számára elfogadhatóbb feltételek közé való menekítés azonban számos nem kívánatos következménnyel járt, mind a gyerekek, mind a családok számára. A gyerekek nélkül maradt családok tovább bomlottak, a családtagokat összekötő kapcsolatok lazultak, egyre kevesebb lett az esélye, hogy valaha újra együtt tudjanak élni.

Ezzel egy időben a gyermekvédelemben dolgozó szakemberek számára is nyilvánvalóvá vált az általuk működtetett rendszer legtöbb diszfunkciója. Egyre világosabb lett, hogy a problémás gyerekek kiemelése és szakemberek által történő nevelése helyett a vér szerinti szülők gyermeknevelési képességeinek fejlesztése, illetve a családok életkörülményeinek a családdal együtt történő javítása eredményezheti hosszabb távon azt, hogy ezek a családok is képesek legyenek saját gyerekeiket a társadalom számára elfogadható módon és körülmények között nevelni.

Mindezen feltételek tették lehetővé, hogy a nyolcvanas évektől a gyermekvédelem (child protection) korábbi gyakorlatát felváltsa a családmegtartás (family preservation) filozófiája és praxisa. A családmegtartó szolgáltatások, és szélesebb értelemben a családok otthonában nyújtott szolgáltatások felé történő elmozdulás alapvető változást jelentett a gyermekjólét területén; „a gyermek megmentése helyett a családnak nyújtott szolgáltatások kerültek a figyelem középpontjába, az egyéni perspektívát felváltotta az ökológiai szemléletmód, mely a környezetet egyszerre tekinti a gyerek és a család problémái forrásának, de ezek megoldási lehetőségének is" (Encyclopedia of Social Work, 1990. 575. o.).

\footnotetext{
${ }^{1}$ A fejezet az Intenzív családtámogató és családmegtartó szolgáltatások c. PhD-dolgozat (2006) részlete
} 
A magyarországi gyermekvédelem más történelmi előzményekkel, más társadalmi kontextusban, de szintén nagy átalakuláson ment át az utóbbi évtizedekben. Az átalakulási folyamat legfontosabb jelzője az 1997-es gyermekvédelmi törvény ${ }^{2}$ megjelenése, melynek elsődleges alapelve a családok megerősítése. Fontos gazdasági, politikai, társadalmi változások folyamatában keletkezett, és átalakította a gyermekvédelem szinte teljes intézményrendszerét.

\title{
Kinek szólnak az intenzív családtámogató szolgáltatások?
}

Több mint fél évszázados megfigyelés, hogy egy adott településen a szociális és egyéb segítő szolgáltatások jelentős részét ugyanaz a néhány család veszi igénybe. Több generációjukkal foglalkoztak már a jóléti szolgálatok munkatársai, több-kevesebb sikerrel. Salvador Minuchin és munkatársai (1967. 219-220. o.) szerint ezek a családok a következőkkel jellemezhetők:

- A folytonosság és a kiszámíthatóság hiánya, mely megnehezíti, hogy a növekvő gyerek a saját világához képest definiálhassa saját magát.

- A személyközi kapcsolatok is hasonlóan szeszélyes és kiszámíthatatlan módon müködnek.

\begin{abstract}
„Ezekben a nagy családokban a gyerekekröl való gondoskodás több különböző személy feladata. Anyák, nagynénik, nagymamák, valamint idősebb testvérek gondoskodnak a kicsikröl. Néha sokféle stimulációt zúditanak rájuk, máskor hosszú időre egyedül hagyják, és a gyerek ott mászkál az üres lakásban. Megvannak a biztonság elemei ebben a több személyes gondoskodásban, de veszély leselkedik a gyerekre azokban az időszakokban, mikor senki nem figyel rá."
\end{abstract}

Minuchin és munkatársai egy későbbi könyvükben ( $P$. Minuchin, J. Colapinto és S. Minuchin, 1998, magyarul 2002) felhívják figyelmünket arra, hogy a jóléti rendszer által ellátott családokban

„... a döntések kivülröl jönnek, és a gyerekek azt tanulják meg, hogy a családban élő felnőtteknek nincs elég erejük. Ez az instabilitás részben a szegénység, a drogok, az erőszak környezetében kialakult életmód, másrészről viszont a társadalmi beavatkozás mellékterméke. A gyerekeket kiemelték, más családtagok börtönben vagy kórházban vannak, és a nekik szóló szolgáltatások szétaprózottak. Nem az a lényeg, hogy ezekre a beavatkozásokra néha szükség van, hanem hogy mindig szétzilálják a család struktúráját. A beavatkozások nem veszik figyelembe a pozitív érzelmi szálakat és fontos lehetöségeket, melyeket így szintén szétrombolhatnak." (Minuchin és munkatársai, 2002. 29-30. o.)

\section{A családmegtartó szolgáltatások jellemzői}

Az Encyclopedia of Social Work (1990. 975. o.) szerint a családmegtartó szolgáltatások a következő öt alapvető célra irányulnak:

- Lehetővé tenni, hogy a gyerekek biztonságosan az otthonukban maradhassanak

- Fenntartani és erősíteni a családi kötelékeket

- Legyőzni a krízishelyzetet, mely miatt a gyereket ki kellene emelni

- Javítani a családtagok megküzdő (coping) készségeit és kompetenciáit

- Segíteni a családot a formális és informális források igénybevételében

A család otthonában nyújtott segítség különféle előnyökkel jár mind a segítő, mind a segítséget igénybe vevő fél számára. A segítő például sokkal jobban megértheti a

\footnotetext{
2 Az 1997. évi XXXI. törvény a gyermekek védelméről és a gyámügyi igazgatásról
} 
család működését a lakásukra vetett egyetlen pillantással, mint az irodájában folytatott hosszú beszélgetések során. A család a segítséget is abban a környezetben kapja, ahol a problémák megjelennek, így közvetlenül lehet kapcsolódni szokásaikhoz, rutinjaikhoz. A segítő így a konkrét helyzetre nézve adhat tanácsot, illetve dolgozhat ki a családdal együtt alternatív megoldásokat. Ez azért rendkívül jelentős, mert az alacsonyabb intellektussal rendelkező, absztrakcióra kevéssé képes családok is profitálni tudnak belőle. A családok otthonában nyújtott szolgáltatásokkal azok a családok is elérhetők, akik rendkívül súlyos problémákkal küszködnek, de sok esetben arra sem képesek, hogy külső segítséget keressenek, vagy a megadott időpontokban rendszeresen megjelenjenek egy intézményben.

\section{A korai életszakasz jelentőségének felértékelődése}

Az utóbbi két évtizedben a fejlett országokban, és hazánkban is, egyre nagyobb figyelem övezi a kora gyerekkort, az iskoláskort megelőző éveket ${ }^{3}$. A korai életszakaszban otthon nevelkedett gyerekek közül igen sokan - többnyire a szegénységben élö, iskolázatlan családok gyermekei - nem lesznek iskolaérettek tanköteles korukra, hátrányaikat nem tudják behozni az iskolai években, sőt ezek tovább fokozódnak. Így egyre sürgetőbb feladat, hogy a társadalom tegyen valamit azért, hogy ezeknek a gyerekeknek sokkal inkább serkentő, alternatív környezetet biztosítson úgy, hogy közben a családi kötelékek is megmaradjanak. A koragyerekkori beavatkozások akkor a leghatásosabbak, ha a családot is megerősítik, ezért a programok egyik célja a szülők támogatása annak érdekében, hogy jobb szülők legyenek, sikeresebben tudják támogatni gyerekeik fejlődését.

A korai beavatkozások jelentőségére az 1970-es évektől az agykutatások is felhívták a figyelmet. Az eredmények azt mutatták, hogy az élet első hónapjaiban, éveiben alakulnak ki, szilárdulnak meg az agyban azok a struktúrák, melyek a későbbi fejlődést meghatározzák. A kora gyerekkort nem lehet többé olyan életszakasznak tekinteni, mikor a gyerek elsősorban csak gondozást igényel. Ezzel egybecseng a közgazdászok figyelmeztetése: a korai életkorban történő beruházások haszna későbbi életkorban megtérül, ha viszont a legkisebb életkorban rossz irányt vesz valami, azt már csak nagy erőfeszítésekkel, magas költségekkel lehet helyrehozni a későbbiekben.

Koragyermekkori intervenciónak a szociális és gyermekvédelmi területen azokat prevenciós szolgáltatásokat tekintik, melyek 0-5 (6) éves korú, sérülékeny családoknak szólnak, céljuk a gyermek minél kedvezőbb fejlődésének támogatása, a család kompetenciáinak megerősítése, valamint a gyermek és a család társadalmi befogadásának (inklúziójának) elősegítése. Eltér a korai fejlesztéstől abban, hogy a (gyógy) pedagógiai módszerekkel nem csak a gyermekre koncentrál, hanem a gyermek és családja, valamint a család és környezete között zajló interakciókat, a sérülékenységet rejtő helyzeteket és rizikótényezőket veszi elsősorban figyelembe, ahol különböző szakterületek képviselői (pl.: szociális munkás, pszichológus, gyógypedagógus, szakorvos, kisgyermekgondozó stb.) dolgoznak együtt a családdal a gyermek optimális fejlődése érdekében. „A koragyermekkori intervenció egy gyűjtőfogalom, amely magában foglalja nemcsak a gyermek konkrét megsegítését, hanem a veszélyeztetett gyermek családjának, a szűkebb-tágabb környezetének támogatását is, egyfajta komplex tanácsadást és beavatkozást." (Csapó és munkatársai, 2015. 34. o.)

\footnotetext{
${ }^{3}$ A Koragyermekkori programok c. tanulmány részlete, In: Szülői szabadságok és koragyermekkori programok (2012).
} 
Az intenzív családmegtartó szolgáltatások jelentős szemléleti rokonságot mutatnak a fenti értelemben vett koragyerekkori intervencióval, bár a kiindulópont nem feltétlenül a 0-5 (6) éves korú gyerek problémája, hanem a család egészéé, de a beavatkozás hatással van a kicsi helyzetére, állapotára is.

\section{Az intenzív családmegtartó szolgáltatások magyarországi tapasztalatai}

Az intenzív családmegtartó szolgáltatások első kísérleti bevezetésére Magyarországon először 2009-10-ben, a RÉV8 Rt. MNP II. Szociális és városrehabilitációs programjában került sor ${ }^{4}$. A projekt ekkor a kerület egyetlen részére, az ún. Magdolna-negyedre korlátozódott, mivel a szociális helyzetet jelző mutatók a kerületben itt a legrosszabbak: itt a legmagasabb a munkanélküliség, a legalacsonyabb a lakók iskolázottsága (a háztartásfők 40 \%-ának végzettsége nem haladja meg a 8 általánost, közülük vannak, akik egyáltalán nem jártak iskolába), a házak és lakások állapota is itt a legrosszabb, és sok család egy lefelé tartó lakásmobilitás során került a negyedbe.

A program tapasztalatai nyomán a Józsefvárosi Önkormányzat Képviselőtestülete 2011 áprilisában döntött arról, hogy az intenzív családmegtartó szolgáltatást önként vállalt feladatként tartós kötelezettségvállalással müködteti az akkori Családsegítő Központ (jelenleg Józsefvárosi Szociális Szolgáltató és Gyermekjóléti Központ) keretében, az MNP II pályázatban meghatározott fenntartási kötelezettségként, egész Józsefvárosra kiterjesztve. A program 2013 márciusától ismét projekt-keretben is folytatódik, a Magdolna Negyed Program III. részeként.

Az intenzív családmegtartó szolgáltatás rövid, időhatáros szociálismunka-szolgáltatás, ami maximum három hónapig tart. Elsősorban krízisben lévő gyermekes családoknak szól, a gyermek kiemelésének alternatívájaként szolgál; vagy éppen a korábban kiemelt és hazakerülő gyerek érdekében erősíti meg a családot. A szociális munkás akár minden nap találkozik a családdal, alkalmanként több órát tölt otthonukban, közvetlen környezetükben, mobiltelefonon munkaidőn túl is elérhető számukra. Egy szakember egy időszakban 2 családdal dolgozik. A szolgáltatást általában a Gyermekjóléti Központ munkatársai ajánlják fel a családnak, de a beavatkozásra csak akkor kerül sor, ha a család ebbe előzetesen beleegyezik. A család részéről az „önkéntesség” nyilvánvalóan korlátozott: néha a szülők szívesen veszik a felajánlott segítséget, más esetben viszont inkább fenntartással vagy némi ellenállással fogadják, annak érdekében, hogy gyerekeik otthon maradhassanak, és a szociális munkásnak jelentős erőfeszítéseket kell tennie a család bizalmának megszerzéséért és az együttműködés kialakításáért. Az intenzív családmegtartó szolgáltatásokra többnyire olyan esetben kerül sor, ahol a családot hosszabb ideje ismerik a Gyermekjóléti Központ munkatársai, esetleg régóta dilemmát okoz, hogy a személyes kötődést jelentő, de rendkívül szegényes körülmények nyújtanak-e jobb esélyt a gyereknek, vagy olyan elviselhetetlen a helyzet a vérszerinti családban, hogy külső elhelyezést kell kezdeményezni - ha indokolt és lehetséges, a kapcsolatok megőrzésével.

\section{Kisgyermekes családok - esetbemutatások}

Sok esetben a nyugati minták alapján meghonosított eljárások hazai környezetben módosulnak az eltérő társadalmi és szolgáltatási környezet hatására. Magyarországon a gyermekjóléti szolgálatoknál dolgozó szociális munkások magas esetszáma nagyon

\footnotetext{
${ }^{4}$ Az Intenzív családmegtartó szolgáltatások. Budapest - Józsefváros c. tanulmány részlete
} 
ritkán teszi lehetővé, hogy egy-egy esettel átmenetileg intenzívebben, esetleg napi több órát, hetente több napot is foglalkozzanak; akkor sem, ha a család nehézségeit nagy valószínűséggel így lehetne enyhíteni. Évekkel ezelőtti elakadások továbblendítéséhez, generációkon keresztül ismétlődő rossz problémamegoldási kísérletek módosításához pedig általában sokkal több idő és intenzívebb, mélyebb kapcsolat kell. Így az intenzív családmegtartó szolgáltatásra sokszor úgy kaptunk felkérést, hogy el kellene intézni ezt vagy azt, el kellene jutnia egy családtagnak valamilyen intézménybe, orvosi kezelésre, de ezt a család valami miatt képtelen megoldani.

A következő esetek bemutatása munkatársaim, Beliczay Eszter, Bereczné Horváth Edit és Csernákné Szabó Mária esetleírásai alapján készült. Az esetek bemutatása során felhasznált nevek a személyiségi jogok védelme érdekében fiktívek, ugyanakkor a főbb demográfiai jellemzők megegyeznek az eredeti esetben szereplő családtagokéval.

A család a Magdolna-negyedben él egy $28 \mathrm{~nm}$-es, galériás lakásban; a család összetétele és müködése meglehetösen rendhagyó. Az édesanya, Tünde 30 éves, törékeny testalkatú, enyhe értelmi fogyatékos asszony, beszéde születési sérülés következtében nehezen érthető. Három kislánya van, akik 5, 6 és 9 évesek. A három gyermek apja a férje, Zoltán, aki együtt él a családdal, gondoskodik a kislányokról. Tündének négy évvel ezelött szerelmi kapcsolata alakult ki a szomszéd lakásban élő Péterrel, aki átköltözött hozzájuk. A kapcsolatukból származó első gyermek elvetélt, a második gyermek érkezése hamarosan várható volt az intenzív családgondozás kezdetén. Ekkorra már Tünde és Péter kapcsolata is fellazult, de mindkét férfi részt vett a család fenntartásában, a gyerekek ellátásában. Mindhárom felnőtt állami nevelt volt, a két férfi éjszakánként együtt járt „lomizni”, majd a gazdagabb kerületek kukáiból összeszedett tárgyakat reggel a konyhában szortírozták és a használhatóbbakat megpróbálták eladni a közeli piacon. Lakásuk ennek megfelelően elhanyagolt, a csótányok gyakorlatilag kiirthatatlanok, nagyobb összegü díjhátralékuk gyült fel.

Az iskola illetve az óvoda jelezte a Gyermekjóléti Központ felé, hogy a kislányok elhanyagoltak, beszédfejlődésük késik, gyakran nincs megfelelö felszerelésük. A védőnő számára kérdéses volt, hogy ebbe a környezetbe hazaengedhetö-e a kórházból a hamarosan születendő kisgyermek. Az intenzív családmegtartó szolgáltatás első szakaszára ebben a helyzetben került sor.

A családgondozó mindhárom felnött szándékait, törekvéseit feltérképezte. Mivel mindhárman részt kívántak venni a család életében, a gyerekek nevelésében, együttes feladat volt a környezet felkészítése az újszülött fogadására. Ez lomtalanitást, nagytakarítást, tisztasági festést jelentett, kiságyat, légzésfigyelőt kellett beszerezni. A gyermek koraszülötten jött a világra, hosszabb ideig kellett kórházban tartózkodnia. Ez- alatt meg kellett oldani a kislányok gondozását, óvodába kísérését is, ami máskor általában az anya feladata volt. A két férfinek néha nehézséget okozott a feladatok összehangolása - ebben az intenzív családgondozó aktív szerepet vállalt. Az anya naponta járt be szoptatni a kicsit, a családnak volt ideje elökészíteni az újszülött fogadását. A család lakásán tartott esetkonferencia nyomán végül a védőnő engedélyezte a kicsi hazahozatalát, így a kisfiú az inkubátort elhagyva nem csecsemőotthonba, hanem saját családjába kerülhetett haza. Az intenzív családgondozás első szakasza ekkor lezárult, de a Gyermekjóléti Központ családgondozója tovább foglalkozott a családdal.

Két év múlva ismét a gyermekintézmények jelezték a gyermekek elhanyagoltságát, ekkor kezdődött az intenzív családgondozás újabb szakasza. A családban ekkor már ott élt Péter új barátnője is; Zoltán a kislányokról gondoskodott, Péter a kisfiáról, Gabiról, a gyerekek anyja pedig próbálta megosztani figyelmét a négy gyerek között. A szülök és a gyerekek erősen kötődtek egymáshoz. Tünde ellátta a gyerekeket élelemmel, Gabit tisztába tette, egyéb anyai feladatok ellátására azonban nem igazán volt képes. Gabi kétéves korában szavakat még nem tudott kiejteni, játékokkal nem tudott megfelelően bánni. Érdeklődése azonban jól felkelthető volt, ha az intenzív 
Intenzív családmegtartó szolgáltatás - a koragyermekkori intervenció egy lehetséges változata

családgondozó kolléga foglalkozott vele, érdeklődő és figyelmes volt, a játékok használatát hamar utánozni kezdte. A családtagok véleménye megoszlott Gabi bölcsődei beíratásával kapcsolatban, a családgondozóval való jó kapcsolat azonban lehetővé tette, hogy együtt végigvigyék a beíratás, beszoktatás nehéz időszakát. Gabi számára a bölcsődében mintha kitágult volna a világ, édesanyja számára először nyillt meg a lehetöség arra, hogy otthonán kívül konyhai kisegítő munkát vállalhasson.

Az intenzív családgondozó napi több órát töltött az otthonukban. Minden felnőtt életéből hiányoztak a koragyerekkori szülöi gondoskodás mintái, így sokszor a családgondozó kollégának kellett megmutatnia, hogy a gyerekeknek mire van szükségük a felnőttől: simogatásra, ölelésre, kedvességre, szeretetre - ezeket az érzéseket nagyon nehezen tudták kifejezni. A kislányokkal gyakran meséltek, báboztak - ebbe egyre inkább Tünde is bekapcsolódott.

Péter apasági nyilatkozatot tett, rendezve ezzel Gabi családi jogállását. Tünde szerette volna, ha dolgozhat, hogy több pénzböl tudjon gazdálkodni, mert férje nem adta haza a keresetét, azonban az élelmiszereket, a napi létfenntartáshoz szükséges feltételeket megteremtette. Pénzt azért nem adott haza János, mert még mindig nem tudta feldolgozni Tünde félrelépését, elmondása szerint még nagyon fájt neki. A pénz visszatartásával akarta büntetni feleségét.

Az intenzív családgondozó segítségével adósságkezelési szolgáltatás kezdődött, így tartozásuk a felére csökkent, részletfizetési megállapodás megkötésével tudták fizetni a hátralékot, a villanyt nem kapcsolták ki a lakásban. Nagyon nehezen, de néha sikerült rávenni őket, hogy takarítsák ki az otthonukat.

A gyermekeket két év múlva, ismét egy iskolai jelzés nyomán kiemelték a családból, de a személyiségfejlődésük számára döntő első éveket otthon tölthették, feltehetően sokkal kevesebb hospitalizációs ártalmat szenvedtek el, mint ha csecsemöotthonban kezdik az életüket. Erős kötődés alakult ki vér szerinti szüleikhez, akik ma is látogatják a gyerekeket a nevelőszülöknél.

\section{A szolgáltatásban részt vevő családok jellemzői}

Természetesen minden család rendelkezik egyedi vonásokkal, a programba kerülö családok élethelyzetében, a családok szerkezetében, megküzdési mechanizmusaiban azonban számos hasonló jellegzetességet figyelhetünk meg. Sokszor dolgozunk egyszülős családokkal, vagy - néha szokatlan összetételü - mozaikcsaládokkal, ahol a szülök nem csak a vér szerinti gyerekeiket nevelik, több élettársi pár és gyerekeik élnek együtt, rendkívül kis alapterületen. Szinte minden szülő alacsony iskolai végzettséggel rendelkezik, az anyák első gyerekeiket általában fiatalkorukban szülték. Ritkán fordul elő, hogy a családból valaki legális, folyamatos munkával rendelkezne (be nem jelentett munka viszont sok családban előfordul). A családok rendszeres bevételeit rendszerint a szociális jövedelmek jelentik; mindenütt jelen van az eladósodottság valamilyen formája (díjhátralék, lakáshitel, magánkölcsönök stb.) A családtagok folyamatosan és aktuálisan is nagyfokú stresszt élnek át, ennek minden következményével együtt. A szülöknél és a gyerekeknél egyaránt gyakran tapasztalunk alacsony önbecsülést, kommunikációs zavarokat, néha agressziót, beszűkültséget, esetenként diagnosztizált, gyógyszeresen és/ vagy rendszeresen kórházban kezelt pszichiátriai betegséget.

A szülők többsége állami gondozásban nőtt fel, vagy hosszú időszakot töltött a vérszerinti családján kívül, ahol sokszoros hiányokat élt át, nem tehetett szert megfelelő gyermeknevelési, illetve a mindennapi élet megszervezésével kapcsolatos tapasztalatokra; gyakoriak a kötődési nehézségek. A nagyobb gyerekek sokszor szülői szerepet töltenek be saját fejlődési szükségleteik feláldozása árán, belecsúsznak egyegy hosszan távol lévő felnőtt családtag szerepébe. A gyenge szülői kontroll, a kiszámíthatatlan irányítás miatt a kortárscsoport hatása felerősödik, föleg serdülőkorban. 
A szülők többségének nincs szakképzettsége, néhányan az általános iskolát sem fejezték be, gyengén tudnak írni, olvasni, többen valamilyen fogyatékossággal élnek. Az iskolával, oktatási intézményekkel való viszonyban gyakran fordulnak elő konfliktusok a szülők rossz iskolai tapasztalatai, szegényes kommunikációs készségei, a gyerekek gyakori betegsége, igazolt vagy igazolatlan hiányzásai miatt. Az iskolában sok gyerek hasonló - ha nem is ennyire rossz - helyzetből jön, a hátrányok gyakran felerősítik egymást, a kompenzálásukra fordítható források sokszor nem elégségesek. A gyakran előforduló rossz egészségi állapot összefügg a lakás állapotával, a szegényes táplálkozással, az összezártságban gyorsan terjedő fertőzésekkel. A mentális betegségek, az anyai depresszió, a szenvedélybetegségek előfordulása nem választható el az életkörülményektől, a folyamatos stressztől.

Az általunk ellátott családok általában rossz minőségü, olykor bontásra ítélt, vagy felújíthatatlan házakban, vizes, dohos, kis alapterületü (25-30 nm-es) lakásokban élnek, több esetben nincs fürdőszoba, vagy ha van is, használhatatlan. A falak sokszor javíthatatlanul rosszak, a csótányok minden erőfeszítés ellenére gyakorlatilag kiirthatatlanok. Néha több családrész él együtt ilyen lakásban, az újszülöttek kivételével senkinek nincs külön ágya, nincs a lakáson belül privát tere senkinek. A tanítási szünetekben, mikor a gyerekek otthon vannak, a mindennapi élet a lakások zsúfoltsága miatt részben az utcán, folyosón, udvaron zajlik, ami gyakori összeütközéshez vezet a kicsit jobb helyzetű családokkal. Minden családban van közüzemi díjhátralék, néhány család szabálytalanul vételez áramot.

A családok többsége csak szociális jövedelmekkel rendelkezik, állandó szegénységben él, a felnőttek energiájának döntő többségét felemészti az aznap túlélése. Néhány esetben a tágabb család besegít a válságos időszakokban, ez azonban olykor kiszolgáltatottá, hosszú távon is függővé teszi az ilyen kötelékekböl kiszakadni nem tudó felnőtt családtagokat. A szülők egy része fél-legális vagy illegális munkával egészíti ki jövedelmét. Egy családban az apa korábban már hosszú időt töltött börtönben és szabadulása évtizedek múlva várható.

Ezekben a családokban általában nincsenek játékok, könyvek, privát terek, íróasztalok/tanulósarkok, minden mindenki szeme láttára történik, se a felnőtteknek, se a gyerekeknek nincs elkülönülési lehetősége. Egyedül a színes tévé, vagy az internet jelenti a „luxus” fogyasztási cikkeket, amit akkor is megszereznek, ha ennivalóra se futja - úgy tủnik, ezek a tárgyak jelentik a társadalomhoz kapcsolódás utolsó láncszemét.

A családok nagy részét hosszú ideje jól ismerik a Gyermekjóléti Központ munkatársai, a gyerekek közül többen voltak a program ideje alatt, vagy már korábban is védelembe véve. Több esetben a család már hosszú évek óta ingadozott azon a határon, ahol a gyerekek kiemelése bármikor szükségessé válhatott volna, vagy ez már meg is történt korábban. Más esetben egy elöre nem bejósolható krízis borította fel a család amúgy is gyenge egyensúlyát, a gyerekeket ki kellett volna emelni az intenzív támogatás lehetősége nélkül.

A Gyermekjóléti Központhoz jelzés érkezett az óvodából, hogy egy egyedülálló édesanya 3 gyermekét neveli. A középső gyermek kócos, piszkos és az anya már a második időpontra se vitte el a gyereket a nevelési tanácsadóba iskolaérettségi vizsgálatra. A Gyermekjóléti Központ családgondozója felajánlotta az édesanyának az intenzív családmegtartó szolgáltatást, amit az édesanya el is fogadott. Az intenzív családgondozás során kiderült, hogy az édesanya 2,5 éve költözött albérletbe, melyet szépen fenntartott, 6 és 7 éves lányait megfelelöen ellátta. Harmadik gyermeke születése óta nem azonban tudott dolgozni, a gyermekekre járó gyes és családi pótlék nem fedezte kiadásaikat. A kevés jövedelem miatt a család létfenntartási problémákkal küzdött, 
Intenzív családmegtartó szolgáltatás - a koragyermekkori intervenció egy lehetséges változata

rezsielmaradást halmozott fel. Az intenzív családgondozóval végiggondolták az albérleten kívüli lehetőségeket, az elmaradás kifizetéséhez adható támogatások lehetőségeit, majd segélykérelmekhez nyomtatványokat töltöttek ki. A kérelem kitöltésénél az édesanya nem akarta beírni, hogy már a szüleitöl külön, albérletben él. Sok munkába került, hogy valódi helyzetét a hatóságok felé is felvállalja. A gyermektartásdíj megelölegezéséhez a szükséges iratokat az édesanya leadta a végrehajtónak. Az édesanya nem akar már visszaköltözni az apjához, anyaotthonba se szeretne menni, így a legkisebb gyermekének apjával elkezdtek azon gondolkodni, hogy szocpolt felvéve vásárolnának egy saját házat vidéken, ez azonban irreális elképzelésnek tünt.

A legkisebb gyereket elöször a Biztos Kezdet Gyermekházba, majd a bölcsődébe is sikerült beíratni. Így már mindhárom gyermek járt köznevelési illetve gondozási intézménybe, az édesanya elkezdett állást keresni. Mivel a legkisebb gyerek nap közben bölcsődében volt, így az édesanya mindkét lányát el tudta vinni a Nevelési Tanácsadóba, a nagyobbikat ezen kívül gyógytestnevelésre is hordta. Sajnos a három gyermek közül valamelyik mindig beteg lett, a tervezett munkafolyamatot felülírta az egészségügyi probléma megoldása. A kislányok nagyon közvetlenek, kommunikatívak voltak, lehetett rájuk építeni. Igazi csajszis programokat lehetett velük szervezni, a fésülködéstöl az öltözködésig, tanulástól a takarításig. Az anya eleinte annak örült, hogy egy másik felnőtt emberrel tudott beszélgetni, tanácsot kérni, majd élvezte, hogy tud a féléves fiára figyelni és a lányok nem idegesítették mindenféle kérdésekkel. Ahogy az idő telt, a feladatok visszaszálltak az anyára, csak már egy strukturáltabb formában, időbeosztás alapján értük el, hogy egyik gyermek se legyen figyelmen kívül hagyva, mindenkire jusson egy kis idő, odafigyelés. Kettős naptárvezetéssel elértük, hogy ne felejtse el az időpontokat, így eljutottak a szükséges kivizsgálásokra. A lakásban közösen elkezdtünk rendet rakni, takaritani. Megbeszéltük, hogy ki mire képes, mit tud felelösségteljesen ellátni. Alternatív tisztítószereket varázsoltunk elő a konyhából (ecet, szódabikarbóna, citromlé), mert nem volt pénz bolti vegyszerekre. Adományokat szereztünk alapítványoktól, így enyhítettük az azonnali pénzhiányt. A három hónap együttmüködés után a család összeszedettebben, koordináltabban müködött együtt. Az óvónők jelezték, hogy tisztább és nem kócos már a kislány, érződik az együttmüködésünk hatása. Sajnos a mélyen gyökerező problémák nem kerültek időben a felszínre, keveset tudtunk vele foglalkozni, de talán ha az anya tényleg elköltözik a szülőktöl messzebbre és nem csak a szomszéd lakásba, valós leválás történik és kénytelen lesz maga megoldani a problémákat, valamint közvetve a gyerekeknél beérik a közös munka gyümölcse. Továbbra is probléma maradt a családnál, hogy az anya és az édesapja, valamint a nevelöanyja között ambivalens a kapcsolat, a papa elöttem is kiabált az anyával, önbecsülését gyermekei elött porig alázva, ezért az anya nem szívesen fordul hozzá segítségért, inkább a két kiskorú gyermekét bízza meg koruknak nem megfelelö feladatokkal. Az anya abból indul ki, hogy tőle is elvárták az átmeneti otthonban, majd a nevelöanyja otthon, hogy rendet tegyen maga körül, mikor annyi idős volt, mint most a lányok. Valószínüleg öt sem tanította meg senki, hogy hogyan csináljon rendet, csak az elvárásokat támasztották vele szemben, most ő is így próbálja tanítani, nevelni lányait. Ezáltal mindig kudarcra volt ítélve a közös munka, mert pár fontos lépés kimaradt a tevékenységböl, a tervezés, feladatmegosztás, a tanítás. Ezt próbáltam a családnál megtanítani, berögzíteni, melyet, ha megtanulnak, átültethető más tevékenységbe is, és az már az ő sikerük lesz.

\section{A szolgáltatás tartalma és intézményi kontextusa}

A szolgáltatás minden esetben a család helyzetéhez, elakadásaihoz, a családtagok erőforrásaihoz és gyengeségeihez igazodik; kiterjed mind a külső környezettel kapcsolatos, mind az egyéni, illetve a kapcsolati nehézségekre. Mivel e szolgáltatástípus esetében nincsenek előttünk korábbi hazai minták, különféle beavatkozási módszerekkel próbálkozhatunk. Gyakran kerülünk kapcsolatba olyan családokkal, ahol a szülő képességeiben, vagy 
lehetőségeiben korlátozott, esetleg fogyatékossággal élő, egyedülálló anya túlterheltsége, gyermekkorában elszenvedett hiányai, kapcsolati nehézségei miatt átmenetileg szinte családtag-helyzetbe engedi be munkatársunkat, és így korrektív élményként élheti át a szülői gondoskodás, a megosztott felnőtt felelösség jelenlétét a családban. A családhoz való átmeneti csatlakozás sokféle együttműködést tesz lehetővé.

Sokszor a család évek óta húzódó elintézetlen ügyeinek (munkakeresőként történő regisztráció, díjhátralék-rendezés elindítása, lakbér-hátralék rendezése stb.) intézésében nyújt segítséget munkatársunk. A családtagok egyrészt nem igazodnak el az intézmények útvesztőiben, másrészt ha meg is találják a megfelelő helyet, összeszedik a megfelelő iratokat, munkatársunk jelenléte, támogatása nélkül nincs elegendő türelmük, kitartásuk a különféle ügyek elintézése során szükséges hosszú sorban álláshoz, a számukra átláthatatlan folyamatok végigkövetéséhez. Olykor egy bírósági tárgyalás kimenetelében is szerepet játszik, ha egy szülö a szociális munkás támogatását maga mellett érezve a legjobb formáját hozza a tárgyalóteremben. Fejlett országokban ún. home-maker szolgáltatások segítik azokat a szülőket, akiknek gyerekkorukban nem volt alkalmuk elsajátítani a háztartás vezetéséhez szükséges tudásokat. Mivel nálunk ez a szolgáltatás még nem létezik, a szociális munkás azt vállalhatja fel, hogy megtanítja ezek elvégzésére a családtagokat. Erre persze csak akkor kerülhet sor, amikor már teherbíró kapcsolat alakult ki közöttük, amikor már szóba lehet hozni, hogy ki kéne takarítani, esetleg érdemes lenne átrendezni a lakást...

A negyedik közös gyermekét váró házaspárt a Gyermekjóléti Központ delegálta az intenzív családmegtartó szolgáltatásba. A család azokban a hetekben költözhetett be a Józsefvárosi Szociális Szolgáltató és Gyermekjóléti Központ egyik krízislakásába. Lakhatási körülményeket tekintve meglehetősen hányattatott időszakon volt túl a család. Korábbi biztosnak tünő albérletüket a férfi betegsége, illetve ehhez kapcsolódó munkanélkülisége következtében elvesztették, így vidékre kényszerültek, majd Budapesten egy családok átmeneti otthonában húzódtak meg. Innen került a család intézményünk krízislakásába, mely lehetőséget teremtett számukra, hogy a maximum egy éves időtartam alatt a kötelezó elötakarékosság révén, legalább annyi egzisztenciát megteremthessenek, hogy a későbbiekben egy számukra megfelelő albérlet kaucióját állni tudják.

A Gyermekjóléti Központ felkérése egyrészt a család lakhatási problémájának megoldására irányult: a család támogatását kérték abban, hogy a krízislakásban tartózkodás minimális feltételeinek eleget tudjanak tenni, illetve a család hosszú távú lakhatásának rendezése érdekében kértek segítséget a lehetőségek felkutatásában.

A megkeresés másrészt a gyermekek közoktatási intézményekbe történő beintegrálásának elősegítésére irányult, mivel ebből korábban problémák adódtak. A házaspár egy 7 éves kislányt, illetve egy 5 és egy 2 éves fiúgyermeket nevelt. Az apának többnyire takarítói állásokban sikerült elhelyezkednie, melyeket gyakran 14-16 órás, illetve esti és éjszakai müszakok jellemeznek. Ebböl a hektikus otthon tartózkodásból kifolyólag a gyermekek nevelése többnyire az édesanyára hárult.

Az első találkozások alkalmával kiderült, hogy az édesanyának az első házasságából született már három gyermeke, akik az édesapánál lettek elhelyezve. Az anya egyáltalán nem tartotta velük a kapcsolatot, nagyon ritkán egy közös ismerösön keresztül érkeztek információk a gyermekekröl. Elejtett mondatokból arra lehetett következtetni, hogy jelenlegi párja miatt hagyta ott első három gyermekét. Mesélte, hogy volt, hogy sírt a gyermekei után, de a párja választás elé állította, hogy vele marad-e vagy visszamegy a gyermekeihez. Mindenesetre erröl nem sokat mesélt az édesanya.

Feltételezhető azonban, hogy ezzel összefüggésben van az, hogy jelenlegi párkapcsolatából származó gyermekeihez rendkívüli mértékben ragaszkodik, nehezen engedi el öket. Ez játszhatott közre abban is, hogy 7 éves lánya későn ment óvodába, illetve sokat kimaradt. A nagyobb kisfiú lassan betöltötte az 5. életévét és még nem járt óvodába. 
Intenzív családmegtartó szolgáltatás - a koragyermekkori intervenció egy lehetséges változata

A közös munka során egyre nyilvánvalóbbá vált, hogy az anya azzal, hogy túlzottan magához köti a gyermekeket, sok területen hátráltatja őket a fejlődésben. Ez számos dologban megmutatkozott. Például az 5 éves kisfiú még cumisüvegből ivott és nem volt szobatiszta, illetve 2 éves öccse elcsendesítésének egyetlen módja - bárhol tartózkodott épp a család - a szoptatás volt. Pár alkalom után szembetünővé vált, hogy az anya nem az életkoruknak megfelelöen bánik a gyermekekkel. A természetes leválás elösegítésének hiányát a gyermekek is megérezték. A szülök erösen tiltakoztak az ellen, hogy gyermekeik köznevelési intézményekbe járjanak. Így azonban a korosztályukhoz képest fejlődési lemaradások mutatkoztak meg a gyermekeken, beszédük, kommunikációjuk, mozgásfejlödésük stb. tekintetében, anélkül, hogy ennek organikus oka lett volna.

Együttmüködésünk során az anyát igyekeztem abban megerösíteni, hogy gyermekeinek szükségük van a köznevelési intézményekre, illetve arra, hogy időben beszoktassa őket. Gyermekei fejlődését segíti a kortárs csoport, illetve az óvoda igénybevétele megkönnyiti az iskolakezdést. Továbbá az újszülött negyedik gyermek mellett nem lesz annyi ideje, ereje, hogy a nagyobbakat napi 24 órában az életkoruknak megfelelően kezelje, számukra programokat, feladatokat biztosítson. A beszélgetések alkalmával az édesanya azzal hárította a nagyobb fiú óvodai beíratását, hogy a sok költözés megviselte a gyermeket, nem szeretné újabb változásoknak kitenni, amúgy is nehezen alkalmazkodik. A helyzet elöre mozdítása érdekében megpróbáltuk mérlegre tenni az óvodával kapcsolatban az érveket, illetve ellenérveket. Végül a kisfiú óvodai beíratása megtörtént, de az anya azt beszélte meg az óvodavezetövel, hogy tavasz helyett inkább szeptembertöl viszi majd a kisfiút, annak reményében, hogy addigra szobatiszta lesz.

A családdal folytatott munka során gyakran kísértem az édesanyát a két fiúval vizsgálatokra, illetve ügyeket intézni. Problémának láttam, hogy az anya egyáltalán nem tudja kezelni a 2, illetve 5 éves gyermek magatartási problémáit. A gyermekek minden alkalommal a környezet számára rendkívül zavaróan viselkedtek. Rendelökben több alkalommal kijöttek orvosok rájuk szólni, hogy zavarják a rendelést. A helyzet azonban ezt követöen sem változott, az anya képtelen volt fegyelmezni öket. A két kisfiú semmiben nem hallgatott rá, az anya egyre agresszívabban szólt rájuk, majd rángatta őket, de a gyermekek mind felülkerekedtek rajta. Félelmetes volt számomra belegondolni abba, hogy pár év múlva, illetve majd kamaszkorban milyen eröviszonyok fognak uralkodni ebben a családban. A következetesség teljesen hiányzott az édesanyából. Próbáltam erröl beszélgetni vele, de jelentösen megnehezítette a helyzetet, hogy az anya nem észlelt problémát, nehézséget a fiúk nevelésével kapcsolatban, annak ellenére, hogy egy kívülálló számára égbe kiáltó volt a helyzet. Elöször azon kellett dolgozni, hogy az anya elfogadja a környezet jelzéseit, hiszen amíg ö nem éli meg problémásnak, nem szenved a helyzetben, addig nehéz bármilyen változást elérni.

\section{Eredmények és kihívások}

Mivel a családokat sokféle hatás éri egyszerre, ritkán egyértelmü, hogy mi az, ami a beavatkozás hatására történik, és mi az, ami ettől független tényezőknek tulajdonítható. Az eredmény sokszor elmaradt eseményekben fogalmazható meg (a szolgáltatás ideje alatt nem alakul ki olyan helyzet, amiért a gyermekek ismételt kiemelése szükségessé válna), vagy olyan lehetőségekben, melyek más családnál evidenciának számítanának (beíratták és beszoktatták a legkisebb gyereket a bölcsődébe, megtörtént a gyerek családi jogállásának rendezése stb.). Olykor az is eredménynek számít, ha az életveszélyes krízisből kilábaló szülő az intenzív segítségnyújtás időszakában nem kerül ismét pszichiátriai osztályra. Máskor a szülők a korábbitól eltérő módon kezdenek foglalkozni gyerekeikkel, illetve elkezdődik a saját élettörténetükkel való szembenézés, ennek átdolgozása is. 
Néha gyorsan sikerült elkezdeni a közös munkát a családdal, máskor sokat kell dolgozni azért, hogy valamilyen megállapodáshoz el tudjunk jutni. A családok határai olykor rendkívül lazák, átengedőek, a segítő könnyen belép, máskor kezdetben ambivalensek, látszólag beengednek, de egy ponton bezárulnak, és nem engednek tovább. Különösen nehéz helyzet ez akkor, ha a segítő azt látja, hogy mindeközben a gyerekek életében fontos esélyek nem valósulnak meg. Ebben az esetben a küldő szervezetnek jelezzük a közös munka elakadását, és esetkonferencia keretében tisztázzuk a további teendőket.

Az intenzív családmegtartó szolgáltatás esetében a szakmai határok másként müködnek, mint a hagyományos munkavégzés esetén. Ha naponta több órát tölt együtt a segítő és a család, általában a család otthonában, közös tevékenységekkel, akkor ez sokkal közvetlenebb viszonyt tesz lehetővé a családtagok és a segítő között, ugyanakkor itt sokkal nagyobb az esélye a túl erős bevonódásnak. Ezért is szükséges, hogy a családdal végzett munka folyamatos szupervízió mellett történjen. Ez egyrészt eset-fókuszú szupervíziót jelent, amire hetente kétszer, a szakmai vezető közreműködésével kerül sor (amit folyamatos telefonos elérhetés egészít ki), másrészt havonta egyszer, az egész szolgáltatást, szervezeti viszonyaival együtt fókuszba helyezö, külső szupervizor által vezetett üléseket.

Az intenzív családtámogatáshoz sok szakember összehangolt együttmüködése szükséges: a Családsegítő és a Gyermekjóléti Központ munkatársain kívül pedagógusok, civil szervezetek munkatársai is részt vettek egy-egy esetben. Az érzelmi leválás akkor sem történik meg egyik napról a másikra, ha megfelelően elő van készítve és a család számára az első pillanattól kezdve világos, hogy a szolgáltatás három hónap múlva véget ér. Azoknál a családoknál, akiknek intenzív támogató beavatkozásra van szükségük, nem csak a szolgáltatások koordinálására, hanem valódi integrálásukra van szükség.

\section{Irodalom:}

Bányai Emőke (2012): Intenzív családmegtartó szolgáltatások. Budapest - Józsefváros. In: Darvas Ágnes és Ferge Zsuzsa (szerk.) Civil jelentés a gyerekesélyekről, 2011. Gyerekesély Közhasznú Egyesület,

URL: http://www.gyere.net/downloads/Civil_jelentes_2011.pdf, (letöltve: 2015. április 17.)

Bányai Emőke és Darvas Ágnes (2012): Szülői szabadságok és koragyermekkori programok. ELTE TáTK, Budapest.

URL: http://tatk.elte.hu/file/SZULOI_SZABADSAGOK_1.pdf, (letöltve: 2015. április 17.)

Csapó Gábor, Cs. Ferenczi Szilvia, Csákvári Judit és Regényi Enikő Mária (2015): Szülőkísérés sérülékeny kisgyermekes családoknál képzés. Hallgatói tananyag, kézirat.

Encyclopedia of Social Work (1990). NASW Press, Washington.

Minuchin, P., Colapinto, J. és Minuchin, S. (2002): Krízisröl krízisre. Animula, Budapest.

Minuchin, S., Montalvo, B., Guerney, B. G., Rosman, B. L. és Schumer, F. (1967): Families of the Slums. Basic Book, London, New York. 